\title{
Beyond risk:
}

\section{Emplacement and the production of environmental evidence}

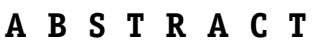

I offer a counterpoint to the prevailing risk literature that focuses not on (mis)perceptions of danger but on the production and circulation of different forms of evidence and the environmental claims they promote. Rather than reproduce the epistemic dichotomies associated with risk discourse, I discuss attempts by waste-industry technicians, government inspectors, lawyers, area residents, and activists to generate persuasive accounts of a large, U.S. landfill and its porous boundaries. I argue that the differential influence of their various claims is best understood by examining what it means to know and care for a place. [risk, evidence, place, epistemology, waste, science and technology]
\end{abstract}

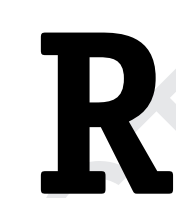
isk calculation - the rational management of indeterminacyappears across multiple arenas of contemporary life, from biomedicine (Rose 2005) and high finance (Lee and Lipuma 2002; Zaloom 2004) to technoenvironmental disasters (Fortun 2001; Petryna 2002) and the war on terror (Amoore and de Goede 2008). As the concept of "risk" became more scientific and stochastic, beginning in the late 19th century, the ability to distinguish between likely and unlikely threats acquired the status of a valued technique. Depending on how they assess and respond to the likelihood of danger, subjects are counted expert or lay, wise or mystified, "sanitary" or "unsanitary" (see Briggs and Briggs 2003:10).

Risk is derived from the Italian rischio, a term that arose in the 16th century among the new merchant classes to account for losses associated with commercial navigation (Hacking 2003:25). Originally, the uncertainties of ocean voyages represented the limits of factual accounting: Balanced, financial bookkeeping required that excessive details about merchant transactions be written out, principal among them, narratives of losses and dangers incurred at sea (Poovey 1998:62-63). If rischio began as other to the numerical, deracinated fact, however, the rise of the insurance industry (Ewald 1991) and probability theory (Hacking 1990) established risks as calculable phenomena, a new social technology to manage future possibilities. When risk later came into prominence in social theory, largely through the writings of Mary Douglas and Aaron Wildavsky (1983), Ulrich Beck (1992) and Anthony Giddens (1991), its reception demonstrated a continuing concern for the contested facticity of dangers and the appropriate stance toward them. Critics of Beck and Giddens identified a realist or "objective-natural" approach in their work-although both authors described a crisis of faith in scientific expertise, they nevertheless maintained the reality of some risks over others (Mythen 2004). Douglas, by contrast, was criticized for suggesting that modern dangers were mere social constructs, leading her to repeat over and over again in Risk and Blame that "the reality of the dangers is not at issue. The dangers are only too horribly real” (1994:29).

In this article, I talk about a situation in which knowledge about danger is at issue: the possibility of a large and controversial U.S.

AMERICAN ETHNOLOGIST, Vol. 38, No. 3, pp. 516-530, ISSN 0094-0496, online ISSN 1548-1425. (C) 2011 by the American Anthropological Association. All rights reserved. DOI: $10.1111 /$ j.1548-1425.2011.01320.x 
landfill leaking contaminants into its surroundings. However, I am less concerned with the "reality" or "construction" of the potential risks attributed to such leakages, how they are differently perceived and managed, than with how the site is experienced and known as a place. In particular, I examine how different social actors attempt to marshal their experiences of place as evidence to make authoritative claims about their surroundings. Evidence has recently gained prominence as a topic of anthropological inquiry (Chua et al. 2008; Csordas 2004; Engelke 2008; Hastrup 2004), though my interest here is with evidence less as a disciplinary or methodological concern than as a general social form and regnant sign in knowledge production. Marilyn Strathern defines evidence as "a construct pointing to practices ... that imply the ability to reduce, digest and otherwise summarise information in such a way [that] other information can be judged, proved or verified" (2008:22). Taken as a sign, evidence indexes the capacity to marshal facts in service of a particular claim. According to Strathern, the use of evidence also suggests a prior separation of "admissible" from "inadmissible" sources of information, accomplished by way of analogical reasoning. Evidence thus resembles an indexical icon, as described by Michael Silverstein (2003), that is, a sign that casually indexes a resemblance between specific facts and more general claims. The perceived admissibility of evidence presupposes such interpretive work.

By exploring contested evidence about places, I attempt to avoid the constructivist-realist analytic dichotomy (see Lupton 1999), which issues from the presuppositions on which the concept of "risk" is based. ${ }^{1}$ Both Gerda Reith (2004) and Christopher Groves (2008) have criticized prevailing risk discourse as an impoverished way of accounting for uncertainty. Following the work of Barbara Adam (1998), they are particularly interested in substituting alternative perspectives on temporality for the calculable futures associated with risk. My complementary aim is to explore the neglected spatiality of uncertainty or, more precisely, the way knowledge claims manifest as evidence of place. If, as Giddens argues, "modernity" is characterized by the "routine contemplation of counterfactuals" (1991:29), any possible worlds people might imagine are ultimately derived from our interactions within the actual worlds we inhabit.

I focus on forms of evidence, as a counterpoint to risk thinking, to accomplish two related objectives. I do so, first, to highlight the process of knowledge production. Like "risk," "evidence" presumes some kind of inferential judgment or calculation, but it also suggests an ongoing knowledge project-whereas risk leads us to ask "of what?" we ask of evidence "for what?" ${ }^{2}$ As I show below, the pursuit of different types of evidence, whether medical, legal, or environmental, sets actors on very different social trajectories. Second, by employing a concept normally reserved for the domain of scientific practice, I highlight the distribution of knowledge work beyond the pernicious lay-expert divide. As I argue below, evidentiary claims about landfills proliferate among waste-industry technicians, regulators, lawyers, those who reside near such facilities, and health and environmental activists, all of whom are actively engaged in projects of truth making.

This latter strategy complements those risk studies, following Brian Wynne (1992, 1996), that attempt to challenge the lay-expert divide by emphasizing the reflexivity and expertise of regular folk and the culturally mediated character of expert knowledge. One of the virtues of Wynne's approach, illustrated more recently in the work of Karen Bickerstaff (2004) and Javier Auyero and Debora Swistun (2007, 2008), is that it demonstrates how the presumed division between expert and nonexpert knowledge is relationally constructed in practice, thereby offering an alternative to the individualistic, rational-choice models of risk favored by Beck and Giddens (see also Briggs 2005, 2011). However, there is always a danger that talking of "lay expertise" or "scientific culture" merely inverts the hierarchy, leaving unquestioned the facticity of risk and the presumed benefit of counting some actors-whether farmers or scientistsas biased, confused, or uncertain. Whether the approach is realist or constructivist, as long as risk is the focus, social relations tend to be sorted into good and bad ways of knowing. Risk discourse seems to generate these epistemic dichotomies again and again.

The concept of "evidence" comes with its own complications, of course, but unlike "risk," it foregrounds its epistemological baggage. It forces consideration of how claims are made, by what means they are justified, shared, and refuted, rather than beginning with the purported illusions and uncertainties of troubled subjects. From this perspective, risk calculations are only one type of evidentiary form in circulation among others. In particular, following Bickerstaff (2004), I suggest that, in many cases, evidentiary disputes that fall under the category of "risk" are encompassed by broader sets of judgments about and care for places.

My approach to place is informed by phenomenology, which emphasizes emplacement, or the material, experiential, and discursive process through which places are creatively elaborated (see Casey 1996). According to Harri Englund, "Emplacement refers to a perspective in which the subject is inextricably situated in a historically and existentially specific condition, defined, for brevity, as a 'place'” (2002:267). Phenomenological approaches to place often emphasize sites where memories and meanings gather, such as homes (Bachelard 1994) and ancestral landscapes (Basso 1996; Feld 1996). Landfills, by contrast, are, ideally, places that gather discarded material in such a way that both waste and waste site can be forgotten and ignored. Englund adds that "emplacement as a phenomenological fact is molded by histories of boundary making and 
constraint" (2002:268). The emplacement of landfills involves knowing and narrating their boundaries, leakages, and ongoing transformation. In this sense, landfills resemble other sites that have been designed to contain exceptional humans and nonhumans-such as hazardous disaster zones (Petryna 2002), refugee camps (Malkki 1995; Turner 2005), protected natural areas (West et al. 2006), and military bases (Lutz 2009). Exceptional places for the "out of place" are carefully controlled and monitored, but their boundaries are porous and may "leak" in a variety of ways. The boundary work undertaken at such sites may involve risk discourse, but it also affords forms of knowledge production beyond what is calculable as "danger."

I begin by discussing the emplacement of a large, landfill in Michigan and the necessity of relying on the landscape's features to develop boundaries and make authoritative claims about their maintenance. Because the process of making landfills also involves interrupting other senses of place, it may be highly contested. I thus trace different ways in which opponents of the landfill seek to redefine these boundaries and make claims concerning the leakage of substances and odors from the site into their neighborhoods and homes. To its local opponents, I argue, the landfill is more than a physical threat: It is also a symbolic anchor that stands for a changing world they are struggling to come to terms with. Although they are very interested in the possible dangers the waste site might pose, they ultimately pursue legal strategies that rely on forms of evidence associated with the enjoyment of property rather than with protecting health.

My aim is not to do away with the concept of "risk," which may be too entrenched in modern social imaginaries for this to be possible in any case, but I offer a critical counterpoint to risk discourse that is motivated by its gaps and silences, ${ }^{3}$ particularly with regard to the lived, experiential aspects of dwelling in and representing one's surroundings. Drawing on the productive tensions within the risk literature does not solve its dilemmas, but it does present suggestive directions for what it means to know and care for places.

\section{Landfill emplacement}

The first time I met Maude, she suggested that if I wanted to understand how Four Corners Landfill was affecting the people of Brandes and the surrounding area, ${ }^{4}$ then I should test the ditches along the county road. "Either that," she said, "or you should do a survey of the people who live around here and ask about their medical problems, because $a$ lot of babies are being born with acid reflux." A middle-aged, white Michigander and grandmother, Maude worked alongside her sister-in-law Gwen at Lions Service, the town's party store and towing operation. ${ }^{5}$ The county road was the main thoroughfare connecting the interstate and the landfill, and dirt and debris often accumulated along it from passing waste haulers. It was along this road that Maude grew up.

Four Corners Landfill became operational late in 1991. The owner had originally intended for it to be built in the woods across from Maude's childhood home, in Calvin Township, but the plan had been heavily opposed by Calvin residents from the surrounding villages of Brandes, Eatonville, and Newton, including Maude's politically active family. Their victory was short lived, however, as another site was eventually selected just down the road, in the poorer, less populated, and more racially diverse township of Harrison. Fourteen years later, working at the store every day, Maude wondered aloud if she was bearing witness to the landfill's impacts on local health:

The acid reflux ... every baby I can think has been born with it. Everyone is on medication for it. Anne's grandson, Anne's got it, and Bill's got it.

I never did have [allergies] but, you know, now I do have problems with my sinus and I never did have ... all of a sudden I'm thinking, "My God, this is terrible!"

You know, is it causing cancers? And I know people die from cancers but it's been a lot.

Maude eventually learned that I did not have the expertise to address her concerns. And although I offered to help find someone who could, in truth, I was immediately skeptical of her claims. For one thing, regulators and health experts do not typically consider respiratory and digestive problems evidence of landfill contamination. The possibility of a landfill releasing carcinogens is a concern, but if that happened, roadside ditches would not be the places to look for them. Waste-disposal companies and regulatory agencies, both in the United States and in other wealthy nations, are heavily invested in preventing contaminants from leaching into groundwater deep below the surface and stray greenhouse gas emissions from escaping into the atmosphere, both of which are thought to pose the greatest threat to environmental and human well-being. ${ }^{6}$

I had been an employee at Four Corners for nine months prior to meeting Maude, and other landfill employees believed as I did. In its early years of operation, Four Corners held regular meetings with community members. Bill Becker, a Lions Service regular, remembers at one meeting trying to discuss the landfill's possible negative health effects, citing many of the same observations Maude had. Those representing the landfill called his claims irresponsible and asked him to leave. Eventually, the meetings stopped altogether and public relations worsened.

How is evidence such as that cited by Maude and other area residents deemed inadmissible? On one level, landfill representatives presuppose that they can trust the bureaucratic procedures they follow; on another, they know that it is not local residents but environmental consultancies 
and regulatory offices, distant "centers of calculation" in Latour's (1987) terminology, that hold a monopoly over risk discourse. The lay epidemiology expressed by Bill was also communicated in area residents' letters of complaint to regulatory authorities who, though sensitive about environmental risks, are committed to a particular model of risk communication that positions them in the role of mediating environmental knowledge. A well-intentioned effort to allay public fears may end up undermining the admissibility of informal environmental and health observations (see Briggs 2011).

I might have been identifying too closely with my former role as a landfill employee to appreciate Maude's perspective. My convictions about the landfill were grounded in the evidence of my experience: I knew the place, I thought, and she did not. Most of the labor I had been doing, in fact, consisted in policing the boundaries of Four Corners, gathering loose rubbish from the roads, ditches, and fences surrounding its borders as well as expanding and repairing its gas well system. All of these activities created the appearance of orderly waste interment, securely cordoned off from the surrounding area. By describing this effort as producing an "appearance" I do not mean to suggest that such spatial organization serves as an artifice, disguising a hidden truth; rather, labor such as mine was meant to shape how others perceived the landfill and felt its presence.

A landfill is a form of emplacement in at least two ways. At the most basic level, it is a place continually in process, a hybrid landscape mechanically sculpted from waste, soil, grass, and a skeletal network of pipes. In another sense, as a political technology that helps to orchestrate the sociomaterial reordering of many places, people, and things, a landfill performs what could be termed "metaemplacement." By gathering and interring out-of-place things, landfills spare people and places from pollution and disruption, a service rendered suddenly apparent when they become full or when waste services fail or workers strike. Both of these emplacement projects, the crafting of a mountain of waste and the multiscalar reordering of places and people through waste circulation, hinge on making and maintaining boundaries. Operating a landfill, or contesting one, means backing up place claims with environmental evidence.

The "sanitary landfill" design that gained worldwide popularity in the mid-20th century failed to account for the migration of contaminants from waste sites to surrounding areas. This problem attracted the attention of the mainstream U.S. public with the Love Canal disaster of the late 1970 s, but it had surfaced long before in a variety of local environmental struggles (Szasz 1994:13-14). In 1976, the United States signed into law the Resource Conservation and Recovery Act (RCRA), which established national standards for the operation and closure of waste sites. Subtitle D of the RCRA made states responsible for determining which of their waste sites fit the criteria for "sanitary landfills"; those that did not were largely deemed illegal. ${ }^{7}$ In the summer of 1993, revisions to Subtitle D came into effect, and new "megalandfills," among them, Four Corners, opened to meet the stricter requirements.

Englund's (2002) approach to emplacement emphasizes the existential and historical unfolding of social projects in the places to which they belong. Places are not "constructed," as landfill managers, technicians, and regulators sometimes suggest, but present affordances for the mutual interanimation of bodies and their surroundings (Basso 1996:55). In keeping with this perspective, the heightened regulatory demands of RCRA have actually forced landfill designers and technicians to draw more on the specific histories and contours of landscapes. At the same time, waste-management personnel need to present the landfill's growth as a governable process, one that can be modeled and contained.

In the past, Four Corners hosted a public open house one day each summer. When I attended the open house in 2005, many of the people present were employees and their families, though some area residents and politicians came by invitation. At the open house, the landfill accepted no business, food was served, and games were available for children, many of whom had their pictures taken while playing on the facility's machines, which had been washed and left on display. While guests enjoyed themselves, the landfill's managerial team focused on circulating its primary message: that the waste was securely contained and properly managed. Cory-the onsite civil engineer-stood beside an informational display, ready to explain how the landfill was designed to protect the community to discuss its future plans. Prominent on his display table were swatches of high-density, geosynthetic liner material, small squares of thick black plastic standing in as evidence of the landfill's impermeability. But the highlight of the open house was the tour of the facility. The landfill supervisor, Bob, and the general manager, known as "Big Daddy," took turns serving as tour guides for buses filled with visitors, describing the passing scenery as they circled the access road, first up the ramp to view the composting operation and dumping area and then back around to the two gasto-energy plants. For this event, the dumping area "up top" was picked clean by laborers and covered with fresh soil and "auto-fluff" (recycled nonmetallic material from automobiles), and the large machines were washed and arranged neatly.

One of things mentioned prominently by Big Daddy during the ride "up top" was that the topsoil in Harrison Township, is underlain by a relatively impermeable clay layer, making the area well suited for landfill construction. ${ }^{8}$ RCRA requires all active U.S. landfills to possess a liner, but a layer of clay provides an extra level of security against possible leaks from the liner's tearing. In the case of Four 
Corners, the layer of clay provides a convenient barrier between compacted rubbish and the groundwater traveling beneath the site, which supplies a number of area homes and farms before emptying into Lake Erie. ${ }^{9}$ But constructing a landfill in such a place also creates certain problems. The impermeable subsoil is one of the reasons that Harrison, like any number of townships along Michigan's southeastern shore, has relatively wet surface conditions throughout the year (Lewis 2002:39). In 2006, for example, a newly constructed leachate tank at Four Corners with a capacity of half a million tons began floating and was partially damaged when the surrounding field suddenly flooded.

Because the ground is rather poor at containing or absorbing storm water runoff, moreover, excess fluid tends to migrate away from the landfill and off-site into surface drains. If such liquid has been in contact with rubbish, it is categorized as "leachate," according to state and federal regulations, and considered a potential contaminant. To successfully control and monitor water runoff and leachate collection, two small streams feeding into nearby farms and long used by the farmers, were rerouted before the landfill was built. To control the flow of water on the landfill property and prevent the accidental migration of leachate offsite or into underground aquifers, diversion berms, perimeter ditches, and pipes were arranged to direct excess runoff into one of several detention bins, where it can be monitored and carefully discharged. By way of a corrective that is at once engineered and naturally occurring, the intended boundary between inside (contaminated leachate) and outside (pure water) is temporarily maintained. ${ }^{10}$

Tours and displays, like boundary fences and paper picking, are meant as public demonstrations of the landfill's containment, its boundedness from the surrounding area. However, RCRA regulations require further sociomaterial elaboration of possible dangers to community and environment. Four Corners pays an independent contractor to monitor its underground wells on a quarterly basis, performing risk assessments to determine the likelihood of serious contamination (i.e., whether trace chemicals exceed allowable limits). Even though Bob, Cory, and Big Daddy have confidence in their geosynthetic liners, water runoff control, and clay deposits, they still measure risks to resident health through carefully sampled and statistically elaborated observations. Regardless of the epidemiological trends of the sort Bill and Maude allege, Bob, Cory, and Big Daddy know their evidence has greater authority, having been assembled within centers of calculation, socially and spatially distanced from local concerns (see Holifield 2008). Just as the waste is contained and managed, so too is expertise.

At the same time, the landfill's managerial and technical staff understand that the growth of Four Corners is in many ways subject to the specific contours and affordances of the very place they seek to control, which is one of the reasons that they have been committed to displaying their representations of the landfill to neighboring residents and state and county politicians. The productive materiality of place, elemental features of landscape like water runoff and wind pattern, for example, not only resist processes of control but also provide opportunities for representations of emplacement. I remember coming into work one morning and running into a smiling Cory in the parking lot, eager to tell me that he had discovered a new way to control odor problems - all that was needed was to install a weather device that would help predict, on the basis of temperature and other environmental patterns, the possible spread of the odor each day. Part of the reason this discovery yielded such excitement for Cory is that he had come to learn over the years that, unchecked, the unbounded circulation of landfill substances affords alternative evidentiary forms and place claims.

\section{NIMBY proxemics}

It has become commonplace in the United States and elsewhere for opponents of unpopular developments to be labeled with the acronym NIMBY (Not In My Back Yard), the implication being that waste activists, for example, are perceived to be more concerned with the general politics of risk distribution—of "social bads," following Beck's (1992) account-than they are with the particular technicalities of waste markets and disposal. The NIMBY caricature offers a convenient method by which to dismiss oppositional claims as parochial and uninformed: Regardless of what sorts of contracts waste companies seek out or how landfills conduct their operations, people will always dislike living in proximity to waste (see Gille 2007:223). If this is true, it follows that nearby residents do not need to be consulted on matters of evidence; rather, evidence needs to be marshaled to correct their errant risk perceptions (see Wynne 1996).

One problem with the NIMBY model is that it tends to separate developments like landfills from other transformations they may bring about or implicate. The very same conditions that draw landfills to marginalized areascheap property, low population density-tend to attract other forms of investment and identification. When I was getting to know them, Maude, Bill, and their friends and neighbors could identify threatening signs all around them. These signs took the form not only of imperceptible chemicals floating in the air or filling roadside ditches but also of new immigrant storeowners down the road, with whom Lions Service competed for customers, and of uppermiddle-class homeowners moving into Silent Pines, the new development of prefabricated homes at the edge of town. For regulars at Lions Service, contamination was legible not only in vulnerable and suffering bodies but also through the general transformation of their surroundings into something new and unfamiliar, where a privileged 
few could acquire million-dollar homes with easy credit and "Middle Eastern" storeowners could claim to be "Italian," evade taxes, and sell "poisoned" sandwiches. Lions Service offered a secure venue for white, rural sociability, where longtime residents could document these changes together.

Since at least 2004, this sense of inexorable change has been embodied, above all, by the growing mountain of waste at the end of the county road. At the same time, one cannot reduce senses of place to a single parameter (namely, proxemics), as the NIMBY model would have it. Maude, for one, did not begin to oppose the landfill until it was acquired by one of the big three transnational waste corporations and the Canadian waste imports began. In 2000, Four Corners gained widespread recognition when its sales team negotiated a ten-year contract with the city of Toronto, accepting over a million tons of municipal solid waste per year and propelling Michigan into the position of the nation's second leading waste importer. ${ }^{11}$ Four Corners became emblematic of out-of-state waste importation, which was elevated to a statewide public concern. Around this time, Maude says, "The traffic got worse, the smells got worse. [Before that] it was more rare, it was like once in a great while." ${ }^{12}$ The statewide politicization of Canadian waste imports may be partly responsible for increased awareness of odors among the landfill's neighboring residents. $^{13}$

In the context of Brandes, the "backyards" of Maude and the other Lions Service activists became representative of the controversial neoliberal and antiprotectionist policies that were allowing waste to travel freely across borders as a good. According to Englund (2002), emplacement offers a perspective on how lived places enact and transform global flows and imaginings, entangling them with particular surroundings. Brandes residents saw their sentiments about the landfill printed, digitized, and televised, sometimes accompanied by their own reported speech, all in the name of opposition to the international waste trade. Outof-state waste became a sporadic obsession for statewide media, linked to the election cycle, but it always positioned Brandes residents at the front lines. "Global" phenomena did not simply produce "the local" but became nested within it, as if the border with Canada had been redrawn along the county road.

Maude relates new markets in waste to a shift in Four Corners' local ethos. Before the Canadian contracts, landfill managers were more responsive: "If you called the dump directly and said, 'Man, there's a smell over here,' immediately they did something about it." In fact, during my time there, Bob, Cory, and Big Daddy were very concerned about odors and devoted considerable time trying to address them. ${ }^{14}$ Maude's view is indicative of a growing divide between local residents and the landfill and its employees: Where once landfill employees were counted among the regular cus- tomers at the store, more business now comes from brokendown Canadian waste haulers looking for a tow.

\section{Olfactory epistemology}

At Lions Service, evidence of the impact of Four Corners was measured daily in the form of talk about odor. Although many things were discussed as I sat ensconced each day in the coffee klatch at Brandes's main party store, conversation frequently turned to whether anyone had smelled the landfill that day and how bad it was.

Brandes and the Silent Pines housing development lie to the northeast of Four Corners, in the path of the prevailing wind. Dust, plastic bags, and construction noise are all carried in their direction, but no "leak" is as contentious as the smells of rotting garbage, sewage sludge, smoldering compost, and landfill gas. ${ }^{15}$ At the time of my research, several times a week, between 5:30 and 6 in the morning, the smell of rotting garbage followed by the stench of sewage sludge was common. Maude correctly attributed this regular succession of smells to the landfill operators digging new trenches (a process that stirs up old waste in the midst of decomposition), into which they dump the daily sludge loads. The large compost piles, assembled on the western side of the landfill for landscaping purposes, also produce fumes; when compost piles are regularly stirred to add oxygen to the batch of rotting plant material, they release a noxious odor. Landfills exhale gas intermittently, depending on the level of biological decomposition within. ${ }^{16}$

This interpretive flexibility of odor, what I would term its semiotic underdetermination (cf. Leach 2001), is precisely what makes smell a difficult form of proof. Recalling Strathern's definition above, to what do acts of olfaction refer? How can this seemingly subjective sense differentiate itself as an admissible source of information? What does it mean to know an odor? One way of dealing with this indeterminacy is to link dispersed encounters with errant smells as semiotic indices of a common reality. On an informal basis, residents do this through odor stories, which serve to fix a shared orientation to a perceptual referent, sometimes to the landfill and other times to their ambient surroundings that it has polluted. Another method is to rely on the relevant authorities-the Michigan Department of Environmental Quality (MDEQ) and the County Department of the Environment (CDOE) - to insure that the infraction is independently recorded and assessed. Both strategies involve a "bodily basis of knowing" place through smell or, paraphrasing Steven Feld, an "[olfactory] epistemology of emplacement” (1996:105). But they employ it to different effect.

In Brandes, sometimes it can seem as if strange smells follow you wherever you go. According to Jerry, Gwen's brother-in-law and a tow-truck operator for her business, "On a bad-smellin day, you smell it everywhere. Sometimes 
it's so bad, you think it's somethin you run over!" As drivers for the towing service move up and down the main highway on a regular basis, they are able to report back on how far the odor travels, as do customers from farther north in Eatonville. Once circulating in the space of the store, these accounts not only relay what conditions are like "outside" but they also bear witness to an alternative cartography of landfill leaks, inscribed in afflicted bodies. At their most extreme, tales of odor encounters become performances of subversive articulations of body and place, as in the oftenused phrases "I thought I was going to puke" and "It was so bad, I almost threw up." One could argue, following linguist Dwight Bolinger (1973), that the pleonastic pronoun $i t$, so often used in English to refer to ambient environmental conditions (e.g., "It's raining"), plays a powerful role in emplacement. Strong odor is here registered as a bodily invasion, a virus, as if the place itself were turning against the bodies of its inhabitants.

William Hanks (1992) describes how speech acts elaborate shared contexts by establishing a common matrix of orientation and perception among participants. In the case of the exchanges about odor at Lions Service and in the surrounding town, the afflicted body creates a shared framework for deictically elaborating place. Each body stands as evidence of unbounded pollution, its temporal and spatial distribution into Brandes and beyond. At Lions Service, people talked about smell so strong "it" made it difficult to get up and go to work in the morning or necessary to close windows on hot days. Maude claims this hurts walk-in business: "As far as them coming into the store, if it smells bad I wouldn't come in. I would go down the street and get to another store before I would get out of my car... Who has an appetite when it smells like that? I mean they're not gonna come in and buy food!" Brandes residents describe having to stay inside on beautiful days rather than have cookouts or play with their children. One woman conveyed her frustration and embarrassment at not being able to have an outdoor high school graduation party for her child.

On another level, landfill odors do not simply fill places with unwanted smells but they displace the "fresh country air" that is said to draw people to the area and that inhabits the fondest memories of lifelong residents. Of course, familiarity with "country smells" can equally serve as a source of local division. Hanks (1992:70-71) points out that a lack of mutuality or symmetry between conversational participants can result in an inability to refer to and occupy the same space. Maude and her friends argue that newer residents often assume that smells coming from the dump are caused by the local sod farm or livestock. Because many of the regulars at Lions Service grew up in the country, they feel qualified to differentiate such smells from landfill odors.

In a similar way, landfill employees accuse both residents and regulators of misidentifying landfill odors. ${ }^{17}$
Timothy, a county inspector, is intensely disliked at the landfill and known for his interest in stray odor. ${ }^{18}$ Bob told me that one time he was forced to escort Timothy around the site for hours to locate a smell that the latter insisted emanated from the landfill. They searched throughout the property until Timothy located the source: a dog carcass in the woods. This story of odor misperception, circulated around the landfill, complements those of odor affliction, but what is at stake in both cases is embodied evidence of the landfill's emplacement.

Inspectors like Timothy typically rely not on their own noses alone but also on complaints called in by local residents. After 2002, calls of this kind increased alongside growing opposition to Canadian imports and the opening of Silent Pines subdivision. ${ }^{19}$ Maude was first given the odorcomplaint phone numbers by Bill, and she displayed them prominently in the store. Maude also encourages customers and friends to call when the opportunity arises: "If people come in and say anything about the smell it's automatic'here's the number to call, you've got to call."' 20 This was part of a new strategy: "They're not gonna do something for one or two people. If one person calls in and says they smell this dump, they're gonna say, 'OK, one person's smellin it.' If you get fifty people callin and sayin they smell this dump, then they're gonna do something." Residents had to begin thinking of making complaints as a form of collective protest, a way of establishing a virtual log documenting the landfill's harmful presence.

An inspector offers independent verification of odor stories, allowing them to serve as admissible evidence in the governance of landfills; this individual does so as an outsider or, more precisely, one whose olfactory capacities belong to no place (see Holifield 2008). Odor problems fall under the county's Air Quality Management Ordinance, which is administered by the MDEQ and the CDOE. ${ }^{21}$ According to the ordinance, landfills are noncompliant if odors are detected at a level of 2 or higher on an odor intensity scale ranging from 0 to 3 . Odor intensity is intended as an "objective" measure of poor air quality, as opposed to the "subjective" perceptions of complainants, who may differ according to their personal thresholds for a given odor or their past experiences with it (see McGinley and McGinley 2000). In addition to odor intensity, an inspector records a description of the "character" of the odor, its duration, and the weather conditions and time during which it occurred.

Inspectors from the county or state actually receive special training that is meant to help them identify specific odor characters and quantifiable intensities in a reliable fashion. Having cultivated a specially trained sense of smell, the inspectors are meant to decontextualize odor qualities in a way that can be usefully contrasted with the fuller embodiment expressed through odor stories, in which the whole body sensorium — mouth, gut, head, and balance — is mediated by the afflictions of the nose. The ideal inspector 
is meant to have, in a sense, a placeless nose, abstracted not only from other elements of and attachments to the surrounding area but from the rest of his or her body as well.

Although few if any local residents have seen the file on Four Corners stored at the regional offices of the MDEQ, the idea of odor complaint as political practice implies some kind of officially sanctioned record of leaks. The odorintensity ranking, as administered by a qualified inspector, is the analogue to the complaint file's systematic gathering of events. Matthew Hull describes the bureaucratic file as a "graphic artifact," the "visible, perduring, physical result of unique (types of) events" (2003:294). As such, the file serves as evidence that a possible infraction took place, a bureaucratic footprint associated with a particular date and time and verified by a government witness. The government inspector, as a witness, serves as a guarantor of the artifact's facticity, enabled by his or her skilled sensorial abstractions.

Because the "untrained" sensory perceptions of residents are deemed inadmissible, they are necessary only to the extent that they alert the attention of accredited inspectors and draw them to an observable episode of landfill odor. With discriminating noses educated through the "placeless" resources of the state and the environmental science establishment, inspectors are empowered to translate the emplaced suffering of residents into noncompliance inspection reports, which, in turn, may lead to notices of violation (NOV) and eventual punitive measures. If a landfill is found to consistently produce odors of 2 or higher, as has happened to Four Corners on more than one occasion, an NOV is submitted to the management team in writing, which stipulates a deadline by which they must correct the problem to avoid accumulating fees.

Odor intensity scales not only represent the socioenvironmental pollution associated with landfills by way of manageable, decomposable units but also perform a structural "state effect" such that regulatory institutions and their judgments seem to transcend the local interests and personal biases in which they are inextricably embedded (see Mitchell 1991). Numerical ranking of odors gives the appearance of objective neutrality and technical precision, making regulators seem impartial and asocial. Because enforcement must be implemented through living bureaucrats and inspectors, however, it is susceptible to mistakes that are also "legible" to governed publics (see Herzfeld 2005). It is well known among inspectors that odor scales are controversial-according to one MDEQ official, many residents find intensities of 1 or 1.5 bad enough to warrant a violation. On another level, many residents of Brandes question the capacity of a dis-placed inspection to render assessments of odor impact in the area, particularly when many inspectors travel long distances to serve as the state's wandering nose; I heard in person or read in the file numerous complaints about inspectors who arrived far too late to assess odors when they were at their peak. This is a problem that the MDEQ inspectors fully admit to and cannot correct, because their offices are approximately fifty miles away by highway, but even the county inspectors, whose offices are less than 20 miles away, sometimes arrive too late to properly evaluate the source of the complaint.

One can easily discern the resulting frustration and desperation in one letter to the MDEQ, dated October 2004, from a resident of one of the local subdivisions:

I have sent several letters regarding this matter. I am being told over and over again that the odor at the landfill has been acknowledged and to expect improvement. The odor has only gotten worse. Today/night the smell was so bad that you could smell it in the closed house. My husband who has severe asthma is having trouble breathing. He had to use his breathing machine tonight and I am concerned that he may have to be taken to the hospital. The air is so bad I can hardly breath [sic]. If you go outside the odor is nauseating.

The writer feels frustrated because, though her complaint has been recorded by the relevant authorities, nothing has been accomplished in response. In fact, odor complaints do result in action. Although this action may not be apparent to complainants, it is in evidence in the accumulated discourse within Four Corners' official file. Sometimes odors are identified that exceed the legal limit and a notice of violation is submitted for consideration. However, this is merely absorbed by the ongoing dialogue between the landfill and regulators concerning day-to-day problems of varying kinds and proposed implementation of solutions.

The MDEQ file on Four Corners includes over a dozen years of inspection reports and e-mail and letter correspondence between residents and regulators as well as reports filed with the agency by the landfill and correspondence concerning proposed renovations, violations, and fines. Ultimately, the material within the file does not present a linear path from violation to punitive action. As Hull (2003) argues, a "graphic ideology" motivates how such records are read and engaged with. One can identify one such ideology in the exchanges between MDEQ officers, locals, and the landfill: that a pragmatic solution is always possible and that each exchange is intended to move toward an eventual resolution of differences. A violation-fine structure creates direct financial incentives to maintain acceptable levels of odor intensity. However, from the landfill's perspective, a violation does not necessarily lead to a fine or a regulatory intervention, but can be discursively managed. While the regulator presses for compromise, the landfill contests interpretations and proposals, playing a game of deferral to the last possible moment.

This ongoing dialogue and its graphic ideology, shaped as they are by prevailing risk politics and a concern for reflexive accounting, sublates any resident claim of contamination, whether epidemiological or olfactory, into the 
continual growth of the file. This is not to say that complaints or lay risk assessments accomplish nothing, only that, from the perspective of Brandes residents, it might appear so. For many, each new odor incident indexes the indifference and failure of the state and local government as much as it does the greed and disdain of the landfill owners. This is partly why some have looked for alternative ways of promoting their interests. Places like Lions Service, moreover, provide an intimate public venue in which to discuss shared disappointments with inspectors and debate other options for accomplishing positive change. At the store, people recognize their own frustration in the stories of others and come to understand their surroundings as afflicted by contamination and a denial or dismissal of their evidentiary claims. Remedying the first would mean mobilizing support for the second.

\section{From risk to nuisance}

So far, I have presented the existing politics of risk governance as somewhat fixed and unimpeachable, a consequence of a monopoly over what counts as evidence for the underlying environmental "reality" of a place. Government and landfill engineers produce knowledge in an ongoing dialogue with one another, collected in the graphic artifact of the file, and regard public observations as, at best, informative but inadmissible and, at worst, distracting and irresponsible. Underlying this separation between "expert" and "lay" forms of knowing is a particular model of discursive interaction, what Charles Briggs terms "communicability" or "the cultural modeling of how discourse is produced, circulates, and is received" (2011:6) and, thereby, "performatively construct[s] the social world" (2011:17). Conflicts over the emplacement of Four Corners are not simply about how risk is perceived but involve a contested model of knowledge production and circulation and how it positions actors in relation to one another.

The contested nature of such models is evident in the history of waste regulations, which continually change in response to the "lay epidemiology" of nonexperts who reside in contaminated spaces, especially their ability to recruit "outsiders" with the necessary expertise and equipment to substantiate their claims (Brown 1992; Holifield 2008; Wynne 1992). Not long before I met the Lions Service activists, a Detroit law firm successfully represented a community in Warren, Ohio, in a class-action lawsuit against a nearby landfill. With the help of the federal Agency for Toxic Substances and Disease Registry (ATSDR), the lawyers established a link between levels of airborne chemicals originating from the waste site and the unusual prevalence of memory loss and cognitive impairment among Warren's inhabitants (see Colledge 2005). The lawsuit was successful, in large part, because of corroborating studies by Kaye
Kilburn and his colleagues on the harmful effects of lowlevel, long-term exposure to sulfur gases (see Kilburn 1997).

The science of risk does not exist abstracted from particular places and disputes but is rooted in evidence derived from contested sites. One could argue that this model represents the kind of "subpolitics" that Beck and others suggest is the appropriate complement to an alienating technobureaucracy of risk, a movement from below that contributes to the reflexive incorporation of new developments and discoveries. Although such an interpretation may suit this and many other examples, I draw attention, instead, to the selection of evidentiary forms, such that alternative indices of place are rendered inadmissible. In part I argue, following Briggs (2011), that this selection process occurs because of a model of risk communication that positions local residents as recipients of knowledge and engineers working for the landfill and the state as authoritative producers of risk discourse. The passion and rhetorical flourish associated with performing social protest (see Graeber 2009) are partly a response to technobureaucratic models of communicative interaction, which conflate lack of poetic language and personal investment with an appropriately "placeless" comportment toward "the facts."

In the spring of 2006, shortly after Bill helped to orchestrate a small protest along the county road, Michigan's Democratic Party contacted the Lions Service activists. In the context of the pivotal Senate and House races of that year, the plight of Brandes residents offered an opportunity to revive a well-worn political issue that had broad public support. Although Maude, Bill, and their associates were ambivalent about contributing to partisan election-year strategies, they needed influential allies; so, for several weeks, they joined incumbent congresswomen in two local rallies-press conferences and a demonstration in Lansing. The actions were strategically held in the weeks prior to an important local hearing in Brandes on the landfill's proposed expansion-local representatives Megan Paterno and Jan Zimmler were supporting a measure in the state legislature that would put a moratorium on further expansion.

The hearing was organized by the MDEQ. ${ }^{22}$ Around one hundred people attended from Brandes and Harrison Township, along with various environmentalists, politicians, and landfill and state employees from the region. Most were from Brandes and opposed to the expansion, though those who spoke publicly were evenly divided. The meeting was structured according to normative expectations about the social conditions that foster communication with the public. It consisted of an overview of the proposed expansion and the application process by Cory, from Four Corners, and an MDEQ representative. Both were dressed neatly and prepared with handouts and displays; they sat near one another at tables situated at the front of the room, facing the audience. In part, their 
introductions were meant to ease public unrest and clarify common misconceptions. ${ }^{23}$

After the presentations, dozens of people waited patiently to make their comments, which ranged from passionate diatribes against the landfill or the MDEQ to carefully delivered statements and short, straightforward questions. Those who defended expansion tended to be businesses that benefited from the landfill or high-ranking members of Harrison's town government; some were booed by the audience. One of the people booed most strongly was a Harrison resident who demanded to know why the hearing was not taking place in her township, the actual site of the dump. To a certain extent, Harrison residents are resented in Brandes for reaping the benefits of Four Corners (e.g., the host fee) while neighboring townships incur the costs. However, as Harrison's supervisor informed the audience (and as he had told Paterno on many occasions), his township had not wanted the landfill either but had been forced by the county to accept it and was now dependent on it for 65 percent of its operating budget. Among other things, these heated exchanges demonstrate a deep local divide over how to characterize the landfill's presence. If most could agree that Four Corners was having harmful effects outside its boundaries, whether by generating odors or addicting a poor township to waste revenue, consensus about how to respond was not forthcoming.

Lions Service activists were frustrated by the model of communicability embodied by the hearing. From the beginning, they felt they were denied a public voice. They were told that their protest signs had to be left outside, but, as they pointed out, the landfill was allowed its own props and diagrams supporting expansion. Whereas they made "lay" and "expert" signs equivalent as opposing claims to speak with authority about the landfill's emplacement, the structure of the hearing denied such symmetry. As an information-gathering forum and not a questionand-answer session, the hearing was intended to let people speak so that their opinions on the matter could be recorded and reviewed, which, for Maude and others, created a sense of speaking without being listened to. Many also felt that the MDEQ and Four Corners were acting as one. ${ }^{24}$ On the one hand, this seemed to perpetuate a division between "laypeople" and "experts" that many already had experienced through the MDEQ's complaint and inspection process. The meeting sent a message that they were not a part of the landfill's governance.

On the other hand, the resemblance between the MDEQ and Four Corners was taken as evidence of collusion: "You could tell it was a done deal," Maude, Bill, Jerry, and others would tell me afterward. The public forum was merely a formality, and everyone from the MDEQ specialist present to Paterno herself was accused of having been "paid off" to smooth the process over. Days after the hearing, activist Jacob came across Paterno at a Big Boy restaurant near
Brandes and confronted her angrily for saying little at the meeting. ${ }^{25} \mathrm{He}$ told me afterward that he was finished with demonstrations and politicians: "They say one thing to your face, and then they laugh at you as you walk away. I want to forget all of it. I hate to say it, but I've given up." Unable to offer their vision of the landfill's local effects as an alternative to the regulator-landfill depiction, Lions Service activists felt politically impotent. Just as the landfill emplaced familiar discards into a transformed landscape and inspectors translated their olfactory sensations into numerical assessments, their political resistance was represented back to them as a conciliatory risk politics.

And yet they had accomplished something. The expansion was only approved on condition that Four Corners demonstrate some commitment to fixing its odor problems. In response, the landfill cancelled controversial sludge contracts with the cities of Detroit and Toronto. The MDEQ had been trying to eliminate these sludge contracts for several years, which it held responsible for noncompliance issues at Four Corners and other sites before it. ${ }^{26}$ The person in charge of evaluating Four Corners' proposal told me that the extensive documentation of verified and unverified complaints against the landfill played a large role in the agency's assessment. If not for the hundreds of odor complaints on record, the MDEQ would have had less leverage in the expansion negotiations.

For Lions Service activists, however, this was not counted as a victory. For one thing, they did not believe sludge shipments would cease, even after it was reported in the local press. After the hearing, it was clear to them that a new approach was needed. Along with another longtime resident and a newer homeowner from Silent Pines, Maude became one of the first to sign an agreement with a Detroit law firm filing a class-action suit against the landfill. The firm was the same one that had successfully represented the community of Warren, Ohio, against a landfill several years before. In that case, plaintiffs had alleged neurological effects from exposure to airborne particles. However, the firm did not think a similar strategy would work for the people of Brandes, in part because the intervention of the ATSDR in Ohio had made the evidentiary process of discovery and the further establishment of epidemiological connections far easier. Furthermore, many of the ailments and diseases frequently attributed to landfill odor in Brandes are not neurobehavioral but respiratory and gastrointestinal. ${ }^{27}$ The process of discovery was ultimately limited, therefore, to symptoms of harm appropriate to a particular kind of legal discourse. The stated objective of the firm was to sue Four Corners for failure to protect local residents from odor and other impacts on their quality of life. This was conveyed in a press release in May: "These residents are being forced to live with this putrid odor all for the sake of profit. It's not even their own trash and yet it affects their quality of life and their property values. This lawsuit is their only recourse." 
A search for an elusive risk of personal injury was replaced with a far more evident claim that Four Corners represented an impediment to the enjoyment of property.

Class actions can only succeed if a sufficient number of people agree to be represented, and middle-class, smalltown Americans are known to be critical of what they see as an excessively litigious society (see Greenhouse et al. 1994). It was to break down such resistance that, in late May, crammed into the basement of the Eatonville Methodist Church, two lawyers attempted to convince several dozen residents to join the class action. During the meeting, they repeated over and over that only hefty financial damages would force Four Corners to change its ways and only legal action could exact such retribution on behalf of Brandes residents. Unlike politicians and regulators, the lawyers were promising to stage a direct confrontation with the landfill. During the question-and-answer session that followed, a number of residents expressed their concern about the firm's intentions. The most commonly asked question was whether the suit was about money or encouraging local change, to which the lawyers repeatedly answered the latter. In particular, they claimed that they would uncover the environmental harms done to the community during the process of discovery and bring them to public light. This claim had obvious appeal to Maude, Bill, and others, who were convinced such an investigation would yield evidence of landfill pollution of land and bodies. But the promise of money brought with it other concerns as well, that a debt relationship would be established that obliged those involved in the suit to surrender something to the landfill in return. Of particular concern for Maude, her friends, and especially those in the area who refused to participate in the suit was that a financial award would foreclose the possibility of later complaints, demonstrations, or suits based on new evidence.

To respond to this concern, the lawyers promised that any further impact on quality of life by the landfill after an agreement was reached would be in violation of the terms of the class action. Furthermore, they guaranteed that a thorough process of discovery would not exclude any legally viable effects of the landfill on the local population. To this end, they insisted that residents participating in the suit carefully fill out "odor surveys" and distribute them to friends and neighbors. The odor survey was offered as a method of translating experiences of socioenvironmental harm into legal representation and penalties, but its purpose was not epidemiological. As one of the lawyers explained to me in private, the primary means of representing the damages wrought by Four Corners is in terms of property, which provides a much better frame than physical harm for torts involving certain kinds of environmental harm, such as odor. Claiming nuisance did not require the same objectively measurable impacts that the allegation of environmental negligence did. Though the odor survey in- cluded a handwritten statement that the respondent should "write any health problems" on the back of the form, one lawyer informed me that bringing perceived health problems into the suit based on what he termed "conspiracy theories" placed the burden of proof on the firm to establish elusive epidemiological evidence, whereas simply proving the existence of a "low-level physical manifestation" of odor in excess of regulated limits was enough to prove a nuisance to personal enjoyment of property. All that was needed was a critical mass of complaints, which, of course, the MDEQ and CDOE already had on file. Unlike county and state regulators, the lawyers did not see odor stories as occasions for empirical verification; rather, odor stories served as legal evidence in aggregate.

At the basement meeting in Eatonville, the class-action lawyers took some of the credit for stopping the sludge contracts, which had been announced the day before the church assembly. The reason that the landfill was now making concessions, they argued, was because of the financial threat that the class action represented. Four Corners hoped that people would give up on seeking damages if the main source of their concerns were eliminated. Many found this claim convincing. Bill mentioned at the meeting that no one should be confident that the landfill would keep sludge out of the community: "Look at their track record" he said. ${ }^{28}$ Arguing that residents needed to keep pressure on the landfill, he bellowed, "You can't let up!" as others nodded agreement.

\section{Conclusion}

In a footnote to his essay in Senses of Place, philosopher Edward Casey briefly describes peculiarly "modern" places where "a thin temporality and a sheer spatiality derive from a placial matrix" (1996:51). These are "architectural and institutional events whose spatiotemporality is literally superficial, a matter of surfaces rather than depths" (Casey 1996:51). He uses prisons and U.S. shopping malls as examples, sites where the ordering of kinds of subjects and objects is very much at issue. He does not deny that such places may continue to hold together instances of space-time, providing a basis, "however inauthentic" (Casey 1996:51) for the gathering of events and experiences. But it is useful to consider how the philosophy of caredfor or auspicious sites depends, recursively, on this "inauthentic" underworld of superficial or thin emplacements. As noted above, most of the deep and enriching places Casey might imagine, notably, homes and familiar enclosures, depend on the expulsion of their unwanted elements elsewhere, to places like Four Corners.

It is constructive, I would argue, to think of landfills (and other sites committed to similar boundary work) as products of these peculiar placial dynamics. To a certain extent, the waste industry and landfill managerial staff hope 
that they can convert millions of pounds of waste into plain and unremarkable terrain where one cannot, as it were, get a grip. Other monumental structures are meant to be seen, admired, and remembered, whereas, in most cases, it is hard to recognize a "capped" landfill, because it has been so carefully sculpted to blend into the landscape. The leakage of odors and other substances, potential or actual, poses a difficulty for such emplacement work, creating depth where there ought to be none.

Despite Big Daddy's assurances that it would never do so, in October of 2009, Four Corners settled the class-action suit. After a three-year struggle, both parties came to terms on condition that the landfill accept no responsibility for wrongdoing, that it invest $\$ 2.5$ million in renovations to improve the site, and that the plaintiffs be barred by a permanent injunction against suing again. The amount of the settlement was $\$ 825,000$. Of that, $\$ 12,000$ was divided between Maude and the other two named clients in the suit, and, after attorney fees, the remaining sum was set aside for other residents to claim. To do so, they had to demonstrate both that they owned property within a designated seven-mile radius of the facility and that they could document a time at which they had complained about landfill odors to the regulatory authorities.

One need not have had one's claim verified-it very well could have been dead dogs and sod farms that residents were detecting. A documented complaint stood as sufficient evidence that one had experienced the landfill as a nuisance, irrespective of the independent reality of the claim. In some ways, this situation recalls the figure of the NIMBY. It is only proximity that matters and the perception of a slight. Without further dialogue or inquiry, concerns about waste markets, environmental governance, and health impacts become reduced to whether one has complained, whether one is a property owner, and where one lives.

The impaired enjoyment of property serves as evidence against the landfill's purported containment of its contaminating substances, which, although not proven, threatened the company enough that it decided to settle. Property enjoyment becomes the common measure of local opposition to the landfill. In an account that parallels her characterization of evidence, Strathern (1996) describes how assumptions of property ownership involve "cutting the network" such that a seemingly limitless array of additional associations and entanglements are lost from view. Just as a privileging of ownership discourse obscures other commitments to and methods of caring for place, an emphasis on impaired enjoyment renders claims of environmental harm and justice or wider concerns about the consequences of neoliberal policies inadmissible.

In U.S. tort law, nuisance claims are often assessed on the assumption that property owners possess a "right of quiet enjoyment" (see Freyfogle 2010). According to some legal theorists, such negative liberty is, in fact, the essence of liberal property entitlement: "the legal ability-not just the physical might - to keep others from interfering with one's acts" (Freyfogle 2010:80). In this view, propertied subjectivity is constituted negatively through the power to contest injury, an interpretation that aligns with Wendy Brown's (1995) characterization of politicized identities within liberalism as "wounded attachments." Those who have endured suffering might possess the right to be compensated for past wrongdoings but are not therefore called on to shape a better future, alongside others who have been wronged or who have wronged them. ${ }^{29}$

Property laws in the United States regarding zoning and torts were reformed extensively over the course of the last century, providing a regulatory complement to the risky mortgage lending of the "ownership society" that would follow (Shoked 2011). The values of home ownership firmly entrenched in U.S. property law by 2006 offered the Detroit law firm a means of anchoring its suit and unifying old and new opponents of the landfill, as well as old and new residents of Brandes, according to a shared parameter. Of course, this would change not long after my fieldwork, when the bursting of the housing bubble would leave behind abandoned prefabricated homes in Silent Pines and other planned communities as evidence of financial alchemy and altogether different sorts of risks, in their own ways more dangerous than the landfill. Although risk would seem to take on a different reality here, the example demonstrates another way in which the concept serves as a "placeless" form of specialist expertise that nevertheless offers a powerful means of constructing facts about, and assessing the worth of, particular places.

My argument has been that much can be gained by setting aside interest in limited calculations of futurity and emphasizing the spatial praxis of contested places as well, the ways they are experienced, narrated, and known. The class-action lawsuit against Four Corners offered some of the residents of Brandes and neighboring towns an opportunity to effect some kind of control over a situation they had been unable to change significantly for over a decade. To do so, they had to search for a form of evidence that would allow them to stake a claim in the ongoing emplacement of Four Corners. Whether the conclusion of the lawsuit changes their perceptions of the landfill or their interest in amassing evidence against it remains to be seen. What is certain is that they will be no less subject to the evidentiary claims of Four Corners and regulatory agencies and that they will still require methods of reckoning and responding to their familiar yet changing surroundings beyond the perception and calculation of risks. 


\section{Notes}

Acknowledgments. The research for this article was made possible through the generous support of the Center for the Ethnography of Everyday Life (CEEL) and the Sloan Foundation. The writing of this article would not have been possible were it not for the additional support of the Waste of the World Programme and the Economic and Social Research Council (RES 000-23-0007). I would also like to thank the anonymous reviewers for their assistance, as well as Catherine Alexander, Karen Bickerstaff, Charles Briggs, Casey High, Stuart Kirsch, Alan Metcalfe, Oana Mateescu, Massimiliano Mollona, Steve Nugent, and Jeanne Reno for helpful discussions along the way.

1. According to Bruno Latour (1999), the realist-constructivist debate that engulfed science studies is part of a modern fascination with the interplay between actuality and artifice, what is really real and what is made up.

2. In the case of contentious or novel claims, further evidence may be gathered to dispute or advance an argument and may involve scrutinizing the underlying "facts" (Strathern 2008:21) or using a claim as grounds for a further demonstration. Like the Peircian sign, evidence begets more evidence in a theoretically endless inferential series.

3. On the uses of contrapuntal tension as a source of dialectical reflection and invention, see Coronil 1995.

4. All proper names of places, people, and businesses have been changed to protect their anonymity.

5. In Michigan and other parts of the Midwest, party store is the colloquial term for a liquor retailer, although such stores also typically sell groceries, lottery tickets, and cigarettes.

6. As Adam (1998) explains, the complex spatiotemporal scales according to which environmental leaks disperse serve to disguise them from direct human perception, intensifying the dangers that they pose.

7. Given the popularity of open dumping in the 20th century, the new RCRA regulations fundamentally transformed the waste industry. Between 1978 and 1988, 70 percent of U.S. landfills closed. Those that remain are increasingly called "megafills," because of their large dumping capacity, or "regional landfills," in reference to their tendency to serve ever-larger geographic markets.

8. In fact, much of eastern Michigan is underlain by heavy deposits of clay-the accumulated product of several millennia of receding glaciers.

9. Big Daddy also told people on the tour that soil conditions in Canada are not ideal for landfill construction, thereby justifying why Four Corners imports so much Canadian waste, a matter of considerable political controversy. In truth, there are a number of landfills in adjacent parts of Canada, and several, not far from Toronto, are sited on substantial deposits of clay in geological conditions as stable as those of eastern Michigan.

10. However, this solution leads to still more complications that must be addressed. One of the redirected streams has since transformed its surroundings into a genuine wetland. Because of their proximity, the perimeter ditches around the landfill tend to sprout cattails-a species used by environmental specialists to identify protected wetland-and attract families of burrowing muskrats, insects, frogs, and even small fish.

11. In 2005, Michigan imported approximately six million tons of waste from beyond its borders, two-thirds of it from Canada.

12. Maude is not alone in her observations. Most residents I spoke with agreed that landfill traffic has worsened in recent years and odors have become much more frequent and intense, especially during the summers.
13. According to records at the Michigan Department of Environmental Quality (MDEQ), odor problems have always attracted more complaints at politically salient moments. When Four Corners sought to vastly expand its available dumping space in 1994, state officials received letters from local residents complaining about terrible smells. In 2003 and 2004, an increase in odor complaints coincided with political campaigns against the waste trade.

14. They took care in positioning the portable perfume-spraying units, and Bob maintained a wood-burning pile behind the home of one of the landfill employees, in the path of the prevailing winds.

15. Sewage sludge, compost, and garbage smells arise from the breakdown of organic molecules, which tends to generate pungent compounds of hydrogen and sulfur. If sufficiently treated, sewage sludge should not smell, but at the time of my research most went untreated prior to burial. Landfill gas is mostly made up of methane, which does not smell but may include traces of ammonia and other pungent chemicals.

16. Additional smells originate from landfill-bound trucks, which may be unwashed or poorly maintained. Many sludge trucks, in particular, seemed to have inadequate covering to prevent foul odors from escaping.

17. Maude has a reputation, among her friends and family, for having an excellent sense of smell and a good memory for different odors. She finds the idea that she could confuse landfill smells with "smells from the country" absolutely ludicrous. Indeed, country smells never really bothered her when she was growing up, and many lifelong residents of the Brandes area feel the same way.

18. The dislike is more often characterized in class terms. Inspectors-like the site's civil engineer, Corey-are college educated and typically dress in casual attire. Like Corey, inspectors are assumed to lack practical know-how and are often mocked for this reason by workers.

19. Many of the new homeowners in Silent Pines had been told that the landfill would close soon only to discover later that it will likely be in operation after they enter retirement.

20. On one occasion, Bill began describing the awful smell near the wetland preserve and was immediately chastised by Maude for not having the complaint number programmed into his cell phone so that he could call in a report right away.

21. This structure is stipulated in Part 115 of Michigan's Natural Resources and Environmental Protection Act, signed into effect in 1994 to meet changing national standards with respect to waste management.

22. State law mandates that changes to the conditions of landfill permits go through a period of public deliberation to provide the agency with as much pertinent information as possible for the construction permit process.

23. For example, the landfill engineer made clear that the changes would not expand the landfill past its existing boundary into hundreds of acres of additional wetlands to the north, as a widespread local rumor had it.

24. I later learned that this appearance was intentional on Cory's part. He wanted people to think the landfill and the regulator had shared interests.

25. For her part, Paterno was disappointed in the hearing as well. Her aide later told me that she had hoped for 500 or more residents to be in attendance and for more to speak out against the landfill and the expansion than did. Her decision to remain polite and conciliatory can be understood, in part, as an effort to remain committed to her whole district. In a town hall meeting in Harrison earlier that year, she had been verbally attacked for suggesting that the Canadian waste trade should be stopped without offering practical ideas to enable the township to avoid going bankrupt without the revenue from that trade. 


\section{Beyond risk - American Ethnologist}

26. Four Corners actually had planned to stop taking in sludge once before, in the face of incredible odor problems in the spring and summer of 2004, but eventually elected to keep the contracts when the situation began to improve and a new odor-prevention plan was implemented.

27. It is possible, however, that gastrointestinal ailments in children could be linked to exposure to fumes from landfill biogas, which is known to carry ammonia (Kaye Kilburn, personal communication 2006).

28. Bill was eventually proven correct. Less than a year later, the landfill began accepting sludge again. However, it is now treated and, according to employees, at least, does not smell.

29. They might be usefully compared with those Ukrainians whose path to citizenship "after" socialism involves negotiating compensation claims for radiation-related illness in the aftermath of the Chernobyl disaster (Petryna 2002). Adriana Petryna describes the attainment of such "biological citizenship" as an uncertain political and biomedical trajectory that simultaneously represents the end of the future lives and relationships radiation sufferers once hoped for (see especially 2002:191-214).

\section{References cited}

Adam, Barbara

1998 Timescapes of Modernity: The Environment and Environmental Hazards. London: Routledge.

Amoore, Louise, and Marieke de Goede

2008 Risk and the War on Terror. London: Routledge.

Auyero, Javier, and Debora Swistun

2007 Confused Because Exposed: Towards an Ethnography of Environmental Suffering. Ethnography 8(2):123-144.

2008 The Social Production of Toxic Uncertainty. American Sociological Review 73:357-379.

Bachelard, Gaston

1994[1958] Poetics of Space. Boston: Beacon Press.

Basso, Keith

1996 Wisdom Sits in Places: Notes on a Western Apache Landscape. In Senses of Place. Keith Basso and Steven Feld, eds. Pp. 53-90. Santa Fe, NM: School of American Research Press.

Beck, Ulrich

1992 Risk Society: Towards a New Modernity. London: Sage.

Bickerstaff, Karen

2004 Risk Perception Research: Socio-Cultural Perspectives on the Public Experience of Air Pollution. Environment International 30(6):827-840.

Bolinger, Dwight

1973 Ambient It Is Meaningful Too. Journal of Linguistics 9:261270.

Briggs, Charles

2005 Communicability, Racial Discourse, and Disease. Annual Review of Anthropology 34:269-291.

2011 Communicating Biosecurity. Medical Anthropology 30(1):6-29.

Briggs, Charles, and Clara Mantini-Briggs

2003 Stories in a Time of Cholera: Racial Profiling during a Medical Nightmare. Berkeley: University of California Press.

Brown, Phil

1992 Popular Epidemiology and Toxic Waste Contamination: Lay and Professional Ways of Knowing. Journal of Health and Social Behavior 33:267-281.

Brown, Wendy

1995 States of Injury: Power and Freedom in Late Modernity. Princeton: Princeton University Press.
Casey, Edward

1996 How to Get from Space to Place in a Fairly Short Stretch of Time: Phenomenological Prolegomena. In Senses of Place. Keith Basso and Steven Feld, eds. Pp. 13-52. Santa Fe, NM: School of American Research Press.

Chua, Liana, Casey High, and Timm Lau, eds.

2008 How Do We Know? Evidence, Ethnography, and the Making of Anthropological Knowledge. Cambridge: Cambridge Scholars Publishing.

Colledge, Michelle

2005 Testimony on ATSDRs Public Health Activities in Warren Township, Ohio. http://www.hhs.gov/asl/testify/ t050511.html, accessed November 19.

Coronil, Fernando

1995 Introduction. In Cuban Counterpoint: Tobacco and Sugar. Pp. ix-lvi. Durham: Duke University Press.

Csordas, Thomas

2004 Evidence of and for What? Anthropological Theory 4(4):473480.

Douglas, Mary

1994 Risk and Blame: Essays in Cultural Theory. London: Routledge.

Douglas, Mary, and Aaron Wildavsky

1983 Risk and Culture: An Essay on the Selection of Technological and Environmental Dangers. Berkeley: University of California Press.

Engelke, Matthew

2008 The Objects of Evidence. Special issue, "The Objects of Evidence: Anthropological Approaches to the Production of Knowledge," Journal of the Royal Anthropological Institute 14(supp. S1):S1-S21.

Englund, Harri

2002 Ethnography after Globalism: Migration and Emplacement in Malawi. American Ethnologist 29(2):261-286.

Ewald, François

1991 Insurance and Risk. In The Foucault Effect: Studies in Governmentality. Graham Burchell, Colin Gordon, and Peter Miller, eds. Pp. 197-210. Chicago: University of Chicago Press.

Feld, Steven

1996 Waterfalls of Song: An Acoustemology of Place Resounding in Bosavi, Papua New Guinea. In Senses of Place. Keith Basso and Steven Feld, eds. Pp. 53-90. Santa Fe, NM: School of American Research Press.

Fortun, Kim

2001 Advocacy after Bhopal: Environmentalism, Disaster, New Global Orders. Chicago: University of Chicago Press.

Freyfogle, Eric T.

2010 Property and Liberty. Harvard Environmental Law Review 34:75-118.

Giddens, Anthony

2001 Modernity and Self-Identity: Self and Society in the Late Modern Age. Stanford: Stanford University Press.

Gille, Zsuzsa

2007 From the Cult of Waste to the Trash Heap of History: The Politics of Waste in Socialist and Postsocialist Hungary. Bloomington: Indiana University Press.

Graeber, David

2009 Direct Action: An Ethnography. New York: AK Press.

Greenhouse, Carol, Barbara Yngvesson, and David M. Engel

1994 Law and Community in Three American Towns. Ithaca, NY: Cornell University Press.

Groves, Christopher

2008(n.d.) Complex Hazards, Technological Futures and Risk. 
Paper presented at the First ISA Forum of Sociology, University of Barcelona, Barcelona, Spain, September 4-8.

Hacking, Ian

1990 The Taming of Chance. New York: Cambridge University Press.

2003 Risk and Dirt. In Risk and Morality. Richard V. Ericson and Aaron Doyle, eds. Pp. 22-47. Toronto: University of Toronto Press.

Hanks, William F.

1992 The Indexical Ground of Deictic Reference. In Rethinking Context, Language as an Interactive Phenomenon. Alessandro Duranti and Charles Goodwin, eds. Pp. 43-77. New York: Cambridge University Press.

Hastrup, Emily

2004 Getting It Right: Knowledge and Evidence in Anthropology. Anthropological Theory 4(4):455-472.

Herzfeld, Michael

2005 Political Optics and the Occlusion of Intimate Knowledge. American Anthropologist 107(3):369-376.

Holifield, Ryan

2008 How to Speak to Aquifers and People at the Same Time: Environmental Justice and Counter-Network Formation at a Hazardous Waste Site. Geoforum 40(3):363-372.

Hull, Matthew

2003 The File: Agency, Authority, and Autography in an Islamabad Bureaucracy. Language and Communication 23:287-314

Kilburn, Kaye

1997 Exposure to Reduced Sulfur Gases Impairs Neurobehavioral Function. Southern Medical Journal 90(10):997-1006.

Latour, Bruno

1987 Science in Action: How to Follow Scientists and Engineers through Society. Cambridge, MA: Harvard University Press.

1999 Pandora's Hope: Essays on the Reality of Science Studies. Cambridge, MA: Harvard University Press.

Leach, Edmund

2001 Taste and Smell. In The Essential Edmund Leach, vol. 2: Culture and Human Nature. Stephen Hugh-Jones and James Laidlaw, eds. Pp. 238-242. New Haven, CT: Yale University Press.

Lee, Benjamin, and Edward Lipuma

2002 Cultures of Circulation: The Imaginations of Modernity. Public Culture 14(1):191-213.

Lewis, Kenneth

2002 West to Far Michigan: Settling the Lower Peninsula, 18151860. East Lansing: Michigan State University Press.

Lupton, Deborah

1999 Risk. London: Routledge.

Lutz, Catherine, ed.

2009 The Bases of Empire: The Global Struggle Against U.S. Military Posts. New York: NYU Press.

Malkki, Liisa

1995 Purity and Exile: Violence, Memory, and National Cosmology among Hutu Refugees in Tanzania. Chicago: University of Chicago Press.

McGinley, Charles M., and Michael A. McGinley

2000 Field Odor Monitoring and Enforcement. Paper presented at the 22nd Annual Hawaii Water Environment Association Conference, Honolulu, June 6-7.

Mitchell, Timothy

1991 The Limits of the State: Beyond Statist Approaches and Their Critics. American Political Science Review 85(1):77-96.

Mythen, Gabe

2004 Ulrich Beck: A Critical Introduction to the Risk Society. London: Pluto Press.
Petryna, Adriana

2002 Life Exposed: Biological Citizens after Chernobyl. Princeton: Princeton University Press.

Poovey, Mary

1998 The History of the Modern Fact. Chicago: University of Chicago Press.

Reith, Gerda

2004 Uncertain Times: The Notion of "Risk" and the Development of Modernity. Time and Society 13(2-3):383-402.

Rose, Nikolas

2005 In Search of Certainty: Risk Management in a Biological Age. Journal of Public Mental Health 4(3):14-22

Shoked, Nadav

2011 The Reinvention of Ownership: The Embrace of Residential Zoning and the Modern Populist Reading of Property. Yale Journal on Regulation 28(1):91-150.

Silverstein, Michael

2003 Indexical Order and the Dialectics of Sociolinguistic Life. Language and Communication 23(3-4):193-229.

Strathern, Marilyn

1996 Cutting the Network. Journal of the Royal Anthropological Institute 2(3):517-535.

2008 Old and New Reflections. In How Do We Know? Evidence, Ethnography, and the Making of Anthropological Knowledge. Liana Chua, Casey High, and Timm Lau, eds. Pp. 20-35. Cambridge: Cambridge Scholars Publishing.

Szasz, Andrew

1994 Ecopopulism: Toxic Waste and the Movement for Environmental Justice. Minneapolis: University of Minnesota Press.

Turner, Simon

2005 Suspended Spaces-Contesting Sovereignties in a Refugee Camp. In Sovereign Bodies: Citizens, Migrants and States in the Postcolonial World. Thomas B. Hansen and Finn Stepputat, eds. Pp. 312-332. Princeton: Princeton University Press.

West, Paige, James Igoe, and Dan Brockington

2006 Parks and Peoples: The Social Impact of Protected Areas. Annual Review of Anthropology 35:251-277.

Wynne, Brian

1992 Misunderstood Misunderstandings: Social Identities and Public Uptake of Science. In Misunderstanding Science? Public Reconstruction of Science and Technology. Alan Irwin and Brian Wynne, eds. Pp. 19-46. New York: Cambridge University Press.

1996 May the Sheep Safely Graze? A Reflexive View of the ExpertLay Knowledge Divide. In Risk, Environment and Modernity: Towards a New Ecology. Scott Lash, Bronislaw Szerszynski, and Brian Wynne, eds. Pp. 44-83. London: Sage.

Zaloom, Caitlin

2004 The Productive Life of Risk. Cultural Anthropology 19(3):365-391.

accepted February 24, 2011

final version submitted March 14, 2011

Joshua Reno

Department of Anthropology

Goldsmiths College

University of London

New Cross SE14 6NW

London

United Kingdom

renojo@gmail.com 